\title{
Types of Ecological Upper Tree Lines at Dalniy Taganai Mountain in the Southern Urals
}

\author{
Marina A. Gurskaya*, Vladimir V. Kukarskih, \\ Andrey A. Grigoriev and Maxim O. Bubnov \\ Institute of Plant and Animal Ecology UB RAS \\ 202, 8 Marta Str., Ekaterinburg, 620144, Russia
}

Received 14.04.2018, received in revised form 15.06.2018, accepted 22.07.2018

Temperature is not the only driver of the upper tree line dynamics in mountain settings. In recent years, researchers have focused on the study of the spatiotemporal dynamics of forest stands under temperature-limiting conditions (at the thermal tree line). The preliminary results of differentiation of ecological types of the upper tree lines of the Siberian spruce (Picea obovata Ledeb.) at Dalniy Taganay Mountain in the Southern Urals are presented. Steepness of slopes and exposure influence the distribution of environmental factors (solar radiation, precipitation and wind) which change growth conditions and form different ecological types of the upper tree line. Four main ecological drivers were noted and four types of tree line were proposed: the thermal, wind, snow and edaphic tree lines. A detailed description of the vegetation cover was done. The revealed types of tree lines are distinguished distinctly based on geomorphologic and topographical features of every study site, the type of the vegetation cover, morphometric characteristics of trees and their annual growth. The edaphic tree line is the longest and the snow tree line is the shortest one. Further studies are needed to more precisely determine the tree line drivers.

Keywords: upper tree line, Siberian spruce, ecological driver.

Citation: Gurskaya M.A., Kukarskih V.V., Grigoriev A.A., Bubnov M.O. Types of ecological upper tree lines at Dalniy Taganai Mountain in the Southern Urals. J. Sib. Fed. Univ. Biol., 2018, 11(3), 237-247. DOI: 10.17516/1997-1389-0068.

(C) Siberian Federal University. All rights reserved

This work is licensed under a Creative Commons Attribution-NonCommercial 4.0 International License (CC BY-NC 4.0).

* Corresponding author E-mail address: mgurskaya@yandex.ru 


\title{
Типы экологических границ леса
}

на горе Дальний Таганай на Южном Урале

\author{
М.А. Гурская, В.В. Кукарских, \\ А.А. Григорьев, М.О. Бубнов \\ Институт экологии растений и животных УрО РАН \\ Россия, 620144, Екатеринбург, ул. 8 Марта, 202
}

На примере горы Дальний Таганай (хр. Таганай, Южный Урал) проведено выделение типов верхних грании леса на основе ведущего экологического фактора, влияющего на морфометрические характеристики ели сибирской (Picea obovata Ledeb.). Крутизна склонов и экспозиция оказывают влияние на распределение экологических факторов (солнечной радиации, осадков и ветра), что в свою очередь ведет к изменению условий произрастания и формированию разных экологических типов верхних грании леса. Следовательно, температура - основной, но не единственный фактор, влияющий на динамику верхней границы леса. Выделено четыре типа грании: термическая, курумная, ветровая и снеговая. На каждой границе дано детальное описание растительного покрова. Показаны различия между границами по геофизическим и топографическим характеристикам склонов, растительному покрову, морфометрическим характеристикам деревьев и их годичному приросту. Наиболее протяженной оказалась курумная граница, наименее протяженной-снеговая.

Ключевые слова: верхняя граница леса, ель сибирская, лимитирующий фактор.

\section{Введение}

Верхняя граница распространения деревьев является важной биогеографической границей распределения деревьев в горах. Здесь в суровых климатических условиях реакция экосистем и, в частности, деревьев на изменения условий окружающей среды наиболее заметна (Горчаковский, Шиятов, 1985; Шиятов, 1986; IPCC, 2013).

В последние годы основное внимание большинства исследователей верхней границы леса сосредоточено на изучении пространственно-временной динамики древостоев в условиях температурного лимитирующего фактора (Mazepa, 2005; Danby, Hik, 2007; Kullman, Öberg, 2009; Moiseev et al., 2010). Однако динамику верхней границы леса в горах лимитирует не только температура. Экологические факторы, ограничиваю- щие подъем верхней границы леса вверх по склону, различны. Они обусловлены топографической сложностью горного рельефа: экспозицией, крутизной склонов, ветрообдуваемостью, снегонакоплением, почвенными условиями и т.д. Поэтому скорость распространения и пространственно-временная динамика распределения одного и того же вида деревьев в пределах одной горной вершины различны.

В настоящее время выделяют несколько групп типов верхних границ леса. Первый способ - границы выделяют на основе различного состава древесных пород, таким образом формируются еловые, лиственничные, кедровые, березовые и т.д. типы границ леса. Другой способ выделения границ основан на дифференциации лимитирующих экологических факторов, таких как температура, 
осадки, ветер. Третья группа верхних границ может быть сформирована различными видами антропогенного воздействия (выпас скота, рубки, пожары), тогда она располагается ниже естественного верхнего предела распространения деревьев (Горчаковский, Шиятов, 1985).

Цель данной работы - выявить основные экологические типы верхних границ леса на примере г. Дальний Таганай на Южном Урале.

\section{Методы}

Район исследований

Хребет Таганай протяженностью 52 км находится в северной части средневысотных Южноуральских хребтов. В тектоническом отношении хребет лежит в пределах Уралтау Центрально-Уральского поднятия Таганайско-Уфалейского антиклинория, где выделяют Таганайскую свиту геологических отложений верхнего протерозоя с выходами интрузивных пород (рис. 1). На хр. Таганай была выбрана вершина Дальний Таганай, имеющая крутые склоны и состоящая из трех гребней. Западный гребень сложен из кристаллических слюдяных сланцевых пород, высотой 1146 м над ур. м. Центральный гребень целиком состоит из кварцита (таганаита) и образует большое плато, покрытое останцами, в восточной части которого расположена метеостанция. Восточный гребень также состоит из слюдяных и слюдяно-гранитовых сланцев, сложенных в форме конической горы (Борисевич, 1968; Геология СССР, 1969).

\section{Климатические условия}

Метеорологическая станция на вершине плато (Таганай-гора, 55²2' с.ш., 5955' в.д., 1102 м над ур. м.) проводила регулярные наблюдения за погодными условиями в период с 1932 по 2001 г. Согласно ее данным, средняя годовая температура минус $1.9^{\circ} \mathrm{C}$, средняя температура января минус $15.4{ }^{\circ} \mathrm{C}$ и июля $12.3^{\circ} \mathrm{C}$; абсолютный минимум составляет минус $33.6{ }^{\circ} \mathrm{C}$, абсолютный максимум температуры $26.6{ }^{\circ} \mathrm{C}$. Отрицательные температуры устанавливаются в первую декаду октября и заканчиваются в последнюю декаду апреля. Сумма положительных темпе-

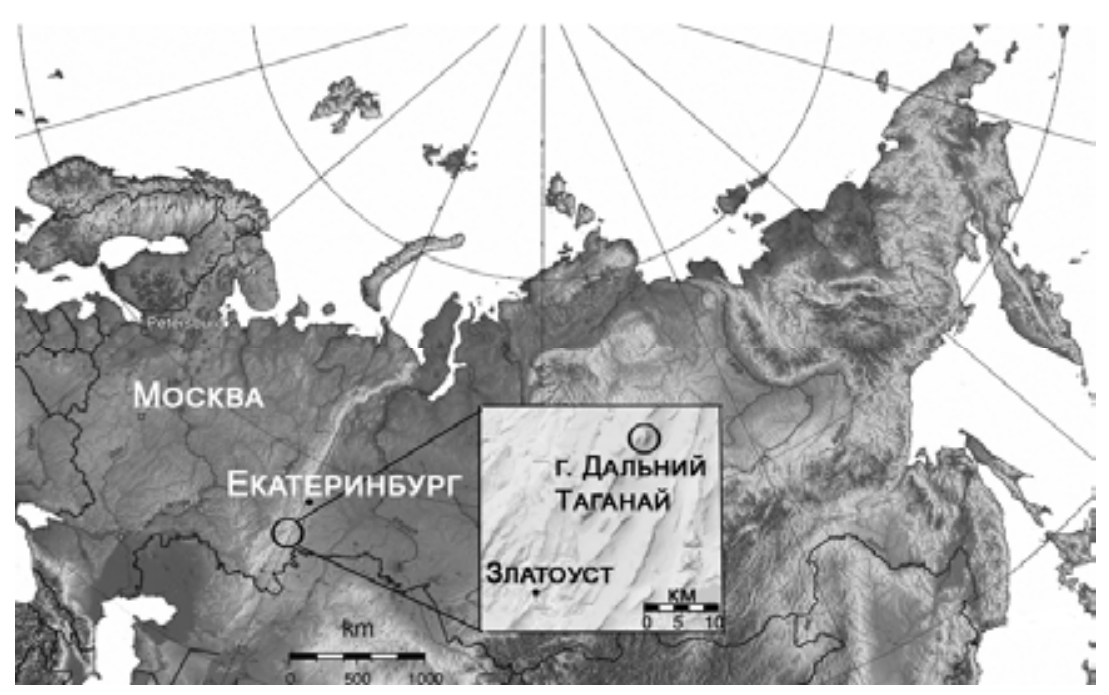

Рис. 1. Карта-схема района исследования. На врезке: хр. Таганай и расположение г. Дальний Таганай

Fig. 1. Map of the study area. Inserted map: Taganay Ridge and location of Dalniy Taganay Mountain 
ратур выше $10{ }^{\circ} \mathrm{C}$ составляет от 800 до 950, продолжительность безморозного периода около 100 дней. Достаточно часто наблюдаются поздние весенние и ранние осенние заморозки, они заканчиваются в первой половине июня, а начинаются в начале сентября, следовательно, продолжительность вегетационного периода здесь составляет от 70 до 90 дней.

На климат района оказывает влияние задержка и существенная трансформация влажных атлантических воздушных масс и циклонов. Среднее годовое количество осадков составляет до 1000 мм, годовое испарение 320 мм. На теплый период года приходится до 70 \% осадков, самый дождливый месяц - июль. Продолжительность периода с устойчивым снеговым покровом составляет до 200 дней; влажность воздуха колеблется в пределах от 64 до 84 \%; средняя глубина промерзания почвы 66 см. Зимой часты метели (132 дня), на протяжении всего года - туманы (240 дней в году).

В районе преобладают ветры западных направлений. Среднегодовая скорость ветра на вершине достигает 10.3 м/с, а максимальная зарегистрированная скорость - более 50 м/с (Агрометеорологический справочник, 1960).

Таким образом, хр. Таганай и, в частности, гора Дальний Таганай, характеризующаяся суровыми климатическими условиями и имеющая маленькую площадь горных тундр на вершине Центрального гребня, представляют собой интересный объект исследования, позволяющий выявить разные типы верхней границы леса, которые расположены на небольшом расстоянии друг от друга. Наличие длинного ряда метеорологических наблюдений делает эту вершину перспективной для дальнейших эколого-климатических исследований.
На вершине горы произрастают ель сибирская (Picea obovata Ledeb.) и береза извилистая (Betula tortuosa Ledeb.), формируя еловую границу леса с присутствием березы на северо-восточном склоне центрального гребня.

Верхняя граница леса в данной работе это узкая полоса относительно однородных условий произрастания, зона между линией, очерчивающей верхнюю границу отдельных деревьев и многоствольных куртин, и более сомкнутыми горными редколесьями. На этом уровне произрастают одиночно стоящие деревья и/или отдельные микрогруппировки деревьев, происходящие от одного корня (многоствольные куртины и многовершинные деревья); выше этого уровня стволовые формы ели не встречаются. Сомкнутость крон не превышает 0.2, и, соответственно, отсутствует средообразующее влияние древесной растительности. Наше представление о верхней границе леса в этой работе ближе к пониманию ее Шретером (Schroeter, 1926) и Шиятовым (Горчаковский, Шиятов, 1985). В некоторых случаях верхняя граница леса совпадает с верхним уровнем экотона верхней границы леса, а иногда, напротив, представляет собой резко очерченную линию. Максимальная высота верхней границы леса на г. Дальний Таганай зафиксирована на высоте 1089 м над ур. м.

\section{Выделение границ}

Для каждого хребта изучали верхнюю границу леса с использованием разновременных аэрокосмических снимков и карт (Google earth, SASPlanet). После этого проводили натурные исследования: обход вершины хребта вдоль верхней границы, осмотр и выявление наиболее очевидных экологических факторов, которые могут обуславливать продвижение границы вверх по склону. 


\section{Модельнье деревья}

Исследования проводили по самой верхней кромке распространения деревьев с учетом однородности условий произрастания и относительно типичных морфометрических характеристик деревьев на выбранной территории. Отыскивали отдельно стоящие деревья или внешние один-два самых крупных ствола у многоствольных куртин, произрастающих на некоторых типах границ. Определяли высоту дерева и диаметр ствола на высоте груди, отмечали наличие флагообразной кроны, двойной кроны, состоящей из приземной нижней кроны высотой до 0.5 м, отделенной от верхней части кроны на 0.5-0.8 м стволом без ветвей. Положение каждого дерева фиксировали с помощью GPS.

\section{Результаты и обсуждение}

Безлесный участок центрального плато г. Дальний Таганай представляет собой небольшую площадку размером $0.4 \mathrm{x} 0.4$ км. В результате обследования этой небольшой горной вершины было выделено четыре основных лимитирующих фактора: температура, ветер, снег и отсутствие почвы. Других факторов, которые распространены в горах Южного Урала и препятствуют продвижению границы леса вверх, не было отмечено. В результате исследования предложено четыре основных типа верхней границы леса.
Типь грании

\section{1. Термическая границ̧а}

Термическая граница располагается наиболее высоко над уровнем моря, так как единственный лимитирующий фактор здесь температура, а другие условия произрастания деревьев очень благоприятные (табл. 1). Такая граница характеризуется пологим склоном (табл. 2), благодаря чему формируется экотон верхней границы леса - плавный переход от уровня сомкнутых деревьев к уровню отдельно стоящих деревьев (рис. 2, А1). Одиночные деревья чаще всего имеют крону симметричной формы, иногда формируют двойную крону (рис. 2, А2). Наблюдаются многоствольные формы, формирующие небольшие куртины. Отсутствие флагообразных крон у ели указывает на защищенные от ветра условия произрастания. Возможно, защиту от ветра дает западный гребень г. Дальний Таганай. Местообитание свежее, с проточным типом увлажнения. Деревья в основном молодые, средний возраст у выбранных моделей составил около 20 лет (табл. 3). Возобновление ели на склоне юго-западной экспозиции обильное, на 20 м встречается до 50 сеянцев высотой до 30 см. Обильный подрост ели перемежается с небольшим количеством подроста березы и иногда сосны высотой до 50 см. Кустарничковотравянистый ярус имеет в своем составе голубику (Vaccinium uliginosum L.), водянику (Empetrum hermaphroditum Hagerup), горец

Таблица 1. Геофизические характеристики типов границ леса на г. Дальний Таганай Table 1. Geophysical characteristics of the four types of upper tree line at Dalniy Taganay Mtn

\begin{tabular}{|c|c|c|c|}
\hline Граница & $\begin{array}{c}\text { Высота над уровнем } \\
\text { моря, м }\end{array}$ & Экспозиция & $\begin{array}{c}\text { Переход к тундре и к } \\
\text { сомкнутому лесу }\end{array}$ \\
\hline Термическая & 1096 & Ю3 & экотон \\
\hline Ветровая & 1077 & Юмешанный \\
\hline Снеговая & 1081 & СВ & резкий \\
\hline Курумная & 1001 & С3 & резкий \\
\hline
\end{tabular}


Таблица 2. Крутизна склонов на разной экспозиции в районе заложенных точек сбора и протяженность выделенных типов границ леса

Table 2. Steepness of slopes at different exposure at tree-ring sites and extension of the four types of upper tree line

\begin{tabular}{|c|c|c|c|c|c|c|}
\hline \multirow{2}{*}{$\begin{array}{c}\text { Характеристика } \\
\text { границы леса }\end{array}$} & \multicolumn{6}{|c|}{ Сторона света } \\
\hline & Север & Восток & Юг & Запад & $\begin{array}{c}\text { Северо- } \\
\text { запад }\end{array}$ & $\begin{array}{c}\text { Северо- } \\
\text { восток }\end{array}$ \\
\hline Тип границы & Термическая & Курумная & Ветровая & Термическая & Курумная & Снеговая \\
\hline $\begin{array}{l}\text { Крутизна склона над } \\
\text { границей (градусы угла } \\
\text { наклона) }\end{array}$ & 3 & 40 & 13 & 8 & 52 & 30 \\
\hline $\begin{array}{l}\text { Крутизна склона ниже } \\
\text { границы (градусы угла } \\
\text { наклона) }\end{array}$ & 9 & 30 & 18 & 10 & 15 & 4 \\
\hline $\begin{array}{l}\text { Протяженность } \\
\text { (\% от общей протяженности) }\end{array}$ & 25 & 30 & 25 & 20 & 93 & 7 \\
\hline
\end{tabular}

Таблица 3. Морфометрические характеристики деревьев на разных типах границ леса на г. Дальний Таганай

Table 3. Morphometric characteristics of trees at different types of upper tree line at Dalniy Taganay Mtn

\begin{tabular}{|c|c|c|c|c|c|c|}
\hline Граница & $\begin{array}{c}\text { Многоствольные } \\
\text { формы }\end{array}$ & $\begin{array}{c}\text { Деформация } \\
\text { кроны / } \\
\text { ствола }\end{array}$ & $\begin{array}{l}\text { Высота } \\
\text { ствола, м }\end{array}$ & $\begin{array}{l}\text { Диаметр } \\
\text { на высоте } \\
\text { груди, см }\end{array}$ & $\begin{array}{c}\text { Средний } \\
\text { возраст на } \\
\text { высоте } \\
0.5 \text { м, лет }\end{array}$ & $\begin{array}{c}\text { Сомкнутость } \\
\text { крон }\end{array}$ \\
\hline Термическая & + & 2 & $1.8 \pm 0.8$ & $3 \pm 1.0$ & 18 & 0.2 \\
\hline Ветровая & - & $2, \Phi$ & $1.6 \pm 0.5$ & $4 \pm 1.8$ & 20 & 0.1 \\
\hline Снеговая & + & И & $0.6 \pm 0.3$ & $3 \pm 0.9$ & 25 & 0.1 \\
\hline Курумная & - & - & $6.0 \pm 1.2$ & $10 \pm 1.0$ & 74 & 0.5 \\
\hline
\end{tabular}

Примечание. Деформация кроны: 2 - двойная крона, Ф - флагообразная крона, И - искривление ствола у основания, «-»- признак отсутствует, «+»- признак присутствует.

альпийский (Aconogonon alpinum (All.) Schur), горец змеиный (Polygonum bistorta L.), ветреницу пермскую (Anemonastrum biarmiensis (Juz.) Holub), толокнянку (Arctrous alpina (L.) Nied.), лишайники рода кладония (Cladonia) и цетрария (Cetraria).

\section{2. Ветровая границ̧а}

Ветровая граница располагается на склоне южной экспозиции. На г. Дальний Таганай этот склон характеризуется повышенной ветрообдуваемостью, так как не имеет есте- ственных топографических защитных барьеров. Несмотря на то, что склон очень пологий, деревья произрастают здесь на несколько метров ниже, чем на термической. Сомкнутый древостой заканчивается здесь резко, очерчивая ветрообдуваемый участок склона (рис. 2, Б1), а затем на пологом склоне формируется уровень редких отдельно стоящих деревьев с флагообразной кроной (рис. 2, Б2). Флагообразная крона формируется из-за иссушающего действия ветра, приводящего к гибели почек с наветренной стороны. Флаги кроны 


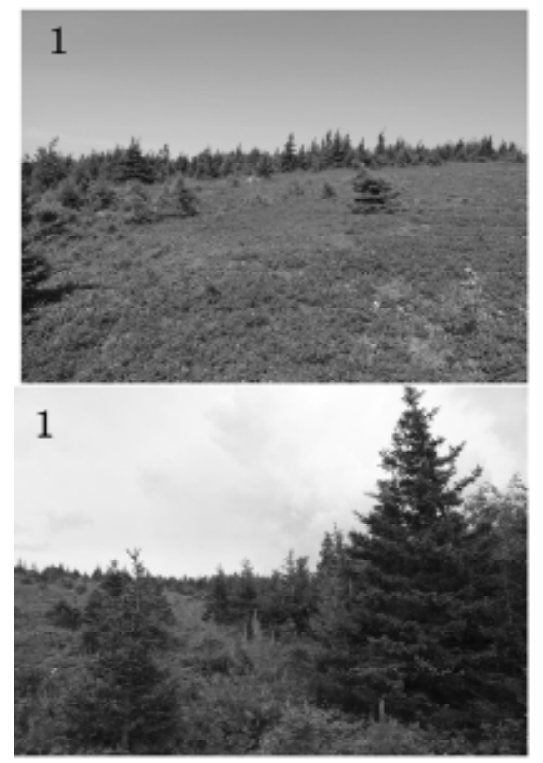

A

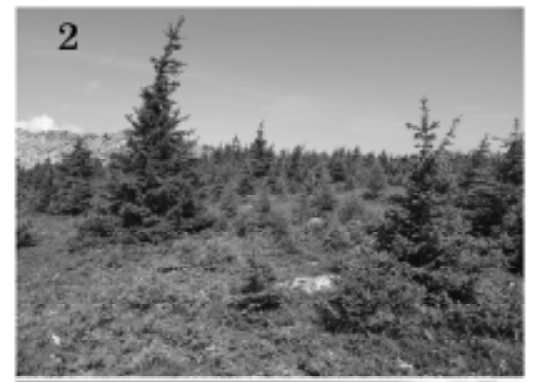

Б
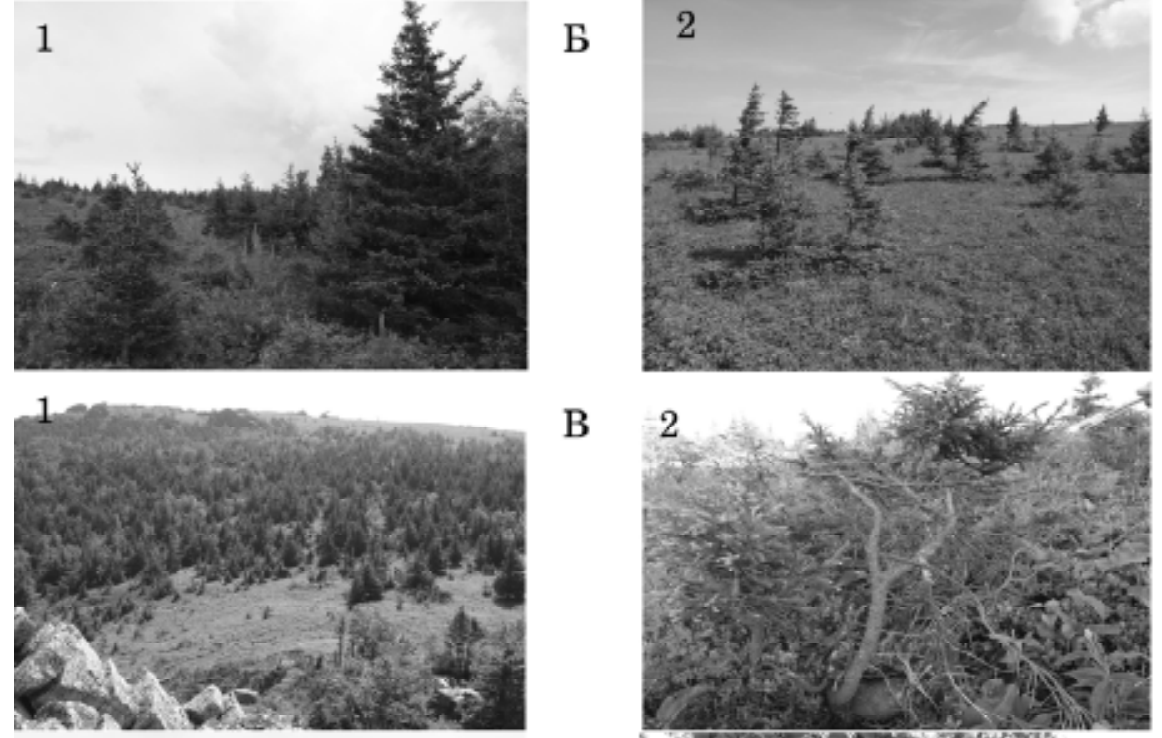

B
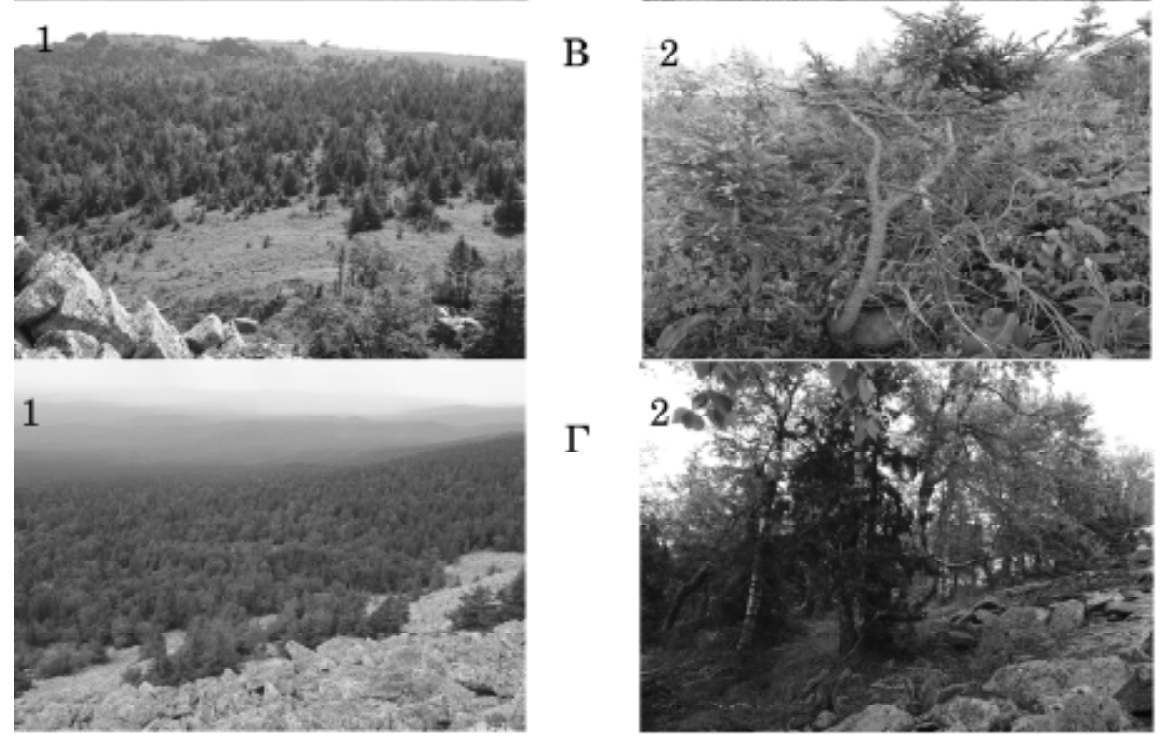

$\Gamma$

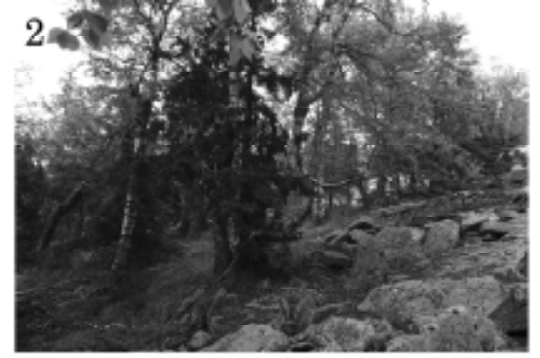

Рис. 2. Типы верхней границы леса на г. Дальний Таганай: А - термическая; Б - ветровая; В - снеговая; $\Gamma$ - курумная; 1 - общий вид; 2 - особенности деревьев и условий произрастания

Fig. 2. Types of upper tree line at Dalniy Taganay Mtn. A - thermal, Б - wind, B - snow, $\Gamma$ - edaphic. 1 - general view, 2 - trees and growing conditions

направлены вверх по склону. Следовательно, на г. Дальний Таганай преобладают ветры южного направления, несущие восходящие потоки воздуха. Отмирание ветвей и повышенная ветровая нагрузка ведут к формированию эксцентричных стволов. Кроме этого, в зимний период наблюдается снеговая абразия стволов выше уровня снега, что ведет к формированию двойной кроны. На г. Дальний Таганай отмечены только одно- и многоствольные формы ели, а стланиковые формы отсутствуют. Средний возраст деревьев около 20 лет. Возобновление слабое, береза встречается единично. Режим увлажнения скорее сухой, что видно по составу травянистокустарничкового яруса. Основными доминан- 
тами являются ветреница пермская, овсяница овечья (Festuca ovina L.) и другие злаки, горец альпийский, водяника, лишайники родов цетрария и кладония.

\section{3. Снеговая границуа}

Снеговая граница представлена очень небольшим отрезком на склоне северовосточной экспозиции западного гребня. На рис. 2 В1 на заднем плане видна линия ветровой границы и частично экотон термической границы с юго-западной экспозицией, а на переднем плане - склон северо-восточной экспозиции с четко очерченной границей снегового типа верхней границы леса. В 80-е гг. XX в. здесь находился снежник, сейчас этот участок характеризуется запаздыванием начала вегетации на 7-10 дней (согласно фенофазе развития растений). Снегонакопление и задержка снеготаяния здесь обусловлены несколькими факторами. Метелевый перенос с вышерасположенных вершин - западного и центрального гребней горы - способствует снегонакоплению в течение холодного периода. Северо-восточная экспозиция склона получает небольшое количество прямой солнечной радиации, и снеготаяние весной происходит очень медленно. В результате совокупного действия факторов эта граница имеет четко очерченный вид, повторяя очертания снежника. Местообитание переувлаженное. Возобновление ели слабое, деревья приземистые, высотой до 0.9 м, с отмершей внизу кроной и изгибами и утолщением ствола у основания (рис. 2, В2). Вертикальные стволы молодые, средний возраст около 30 лет. Однако не исключено, что фактический биологический возраст этих елей гораздо больше, а усиленный рост вертикальных стволов наблюдается в последние 25-30 лет. Деревья имеют отмершую внизу ствола крону с сохранившимися усохшими ветвями.
Живая крона имеет близко расположенные ветви, очень густая, что указывает на медленный прирост в высоту в течение вегетации (рис. 2, В2). Большинство деревьев многовершинные и/или многоствольные. У основания ствола все деревья имеют утолщение или изгиб, указывающий на частое отмирание латеральных почек, ветвей и осевого побега. Пробуренные на высоте 0.20.3 м стволы имеют камбиальный возраст в среднем около 25 лет. В кустарничковотравянистом ярусе основными доминантами являются: водяника, толокнянка, горец альпийский, ситник трехраздельный (Juncus trifidus L.), ветреница пермская, папоротник.

\section{4. Курумная границุа}

Самый распространенный тип границы на г. Дальний Таганай - это курумная. Продвижение границы вверх лимитируется наличием большого количества хаотически нагроможденого крупного обломочного материала, формирующего крутые склоны вершин. Эта граница чаще всего приурочена к склонам северной и восточной экспозиций, но ведущим фактором ее формирования, ограничивающим продвижение ее вверх по склону, является крутизна склона, превышающая $30^{\circ}$. В результате деревья произрастают очень низко над уровнем моря, а сама граница распространения деревьев выглядит резко очерченной (рис. 2, Г1). Почвенный покров слабо развит, а на самих курумах практически отсутствует, подъем деревьев вверх ограничен отсутствием субстрата для произрастания. Высокие деревья формируют сомкнутый древостой, с выраженным подлеском, состоящим из березы, шиповника и рябины (рис. 2, Г2). Средний возраст собранных деревьев составил 74 года, а у самого старого модельного дерева - 150 лет. Возобновление ели слабое из-за высокой конкурен- 
ции. Травяно-кустарничковый ярус состоит из черники, разных злаков, ситников, папоротников и зеленых мхов рода Pleurocium. Местообитание с проточным типом увлажнения, свежее.

\section{Крутизна склонов на разных типах гранич}

Платообразная вершина г. Дальний Таганай имеет склоны различной крутизны на разных сторонах света и на разных типах границ (табл. 2). Крутизна склонов способствует или препятствует продвижению границы вверх, что хорошо просматривается на примере термической и курумной границ соответственно. Над курумной границей угол крутизны склонов превышает $40^{\circ}$, склоны состоят из крупнообломочного материала, без почвенного слоя, тогда как над термической и ветровой склоны очень пологие (крутизна меньше $15^{\circ}$ ) и имеют благоприятные условия для продви- жения границы вверх. Склоны горы ниже современной верхней границы распространения ели на Дальнем Таганае характеризуются относительно пологим склоном с углом наклона до $30^{\circ}$. Наиболее пологие склоны находятся под термическими границами, что позволяет деревьям формировать экотон верхней границы леса.

\section{Соотночение типов границ}

Исходя из полученных данных, была построена карта-схема распределения разных типов границ на г. Дальний Таганай (рис. 3). Наиболее распространенным типом границы является курумная, или эдафическая. В зависимости от крутизны склонов она составляет до 30 \% всей длины верхнего предела распространения ели на центральном гребне и до 90 \% на западном гребне г. Дальний Таганай (табл. 2). Термическая граница состав-

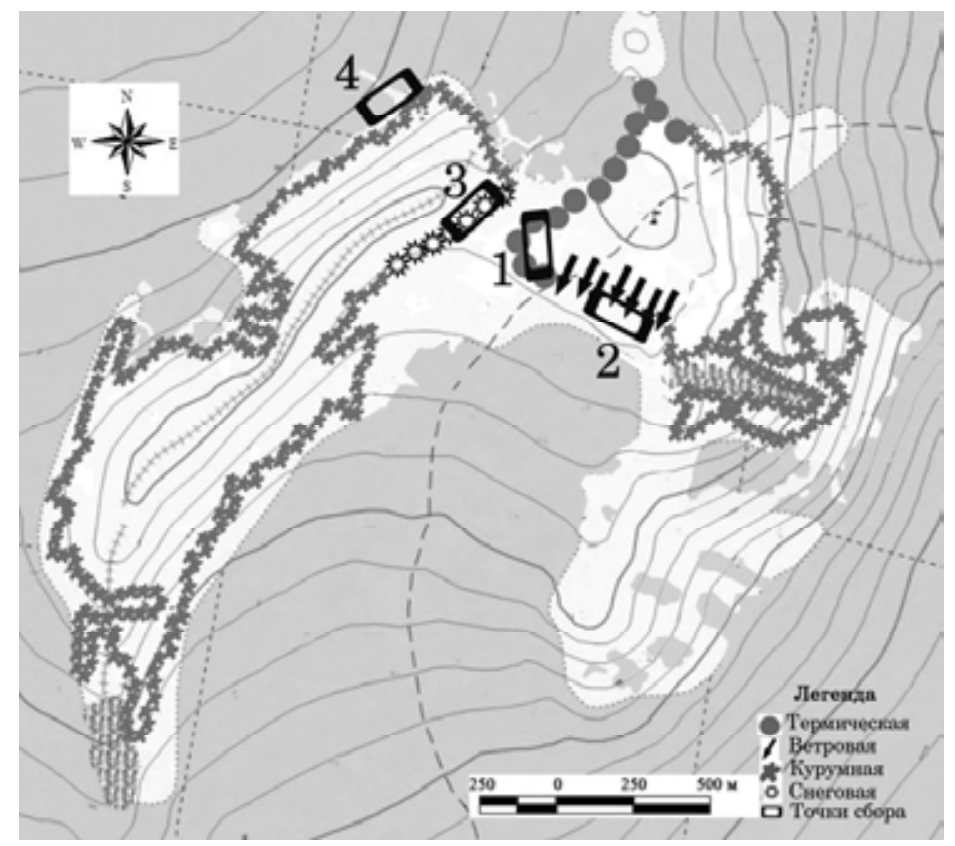

Рис. 3. Карта-схема распределения экологических границ леса на г. Дальний Таганай. Темная серая заливка - территория, покрытая лесом в 50 -е гг. XX в. 1, 2, 3 ,4 - соответствуют участкам А, Б, В, Г на рис. 2

Fig. 3. Distribution of ecological types of the upper tree line at Dalniy Taganay Mountain. The gray color fills the territory covered by forest in 1950s. 1, 2, 3 , 4 correspond to sites A, Б, B, $\Gamma$ in Fig. 2 
ляет в целом до 45 \% от длины центрального плато и состоит из границы юго-западной и северо-западной экспозиций. Она приурочена к благоприятным условиям произрастания, создаваемым рельефом и экспозицией. Ветровая составляет 25 \% от всей длины. Она также приурочена к пологим склонам, но из-за сильных ветров здесь формируются специфические формы роста деревьев. Наименее протяженной является снеговая граница, которая находится вдоль снежников и многоснежных местообитаний и составляет 5 \% длины на западном гребне. Исторически этот тип границы не был протяженным. В связи с недавними изменениями климата и повышением температуры воздуха (Моисеев и др., 2016) снеговая граница постепенно уменьшается и зарастает елью, березой и кустарниками.

\section{Заключение}

В работе представлены предварительные результаты выделения разных типов верхней границы леса на г. Дальний Таганай на Южном Урале. Выделение границ основано на влиянии различных экологических факторов, таких как температура, ветер, снежный покров и наличие почвы, в результате чего описано четыре типа границ: термическая, курумная, ветровая и снеговая. Выявленные типы границ имеют выраженные отличия между собой как на основе топографии (экспозиция, крутизна склонов и высота над уровнем моря), так и по морфометрическим характеристикам деревьев. Необходимы дальнейшие исследования, более точное определение лимитирующих факторов, изучение смешанных и переходных форм границ, таких как курумно-ветровая, термическая-ветровая.

Сбор полевого материала, построение карт распределения границ и их анализ выполнены при поддержке РФФИ (проект № 15-04-04933), измерение годичных колец и интерпретация результатов - в рамках государственного задания Института экологии растений и жсивотных УрО РАН № 0400-2014-0024.

\section{Список литературы}

Агроклиматический справочникпо Челябинскойобласти (1960) Главное управление гидрометеорологической службы при Совете Министров СССР. Уральское управление гидрометеорологической службы. Свердловская гидрометеорологическая обсерватория. Л., Гидрометеоиздат, 156 c. [Agroclimatic book for the Chelyabinsk region (1960) Head of Hydrometeorological Service of the Minister Council of the USSR. Ural Department of Hydrometeorological Service. Sverdlovsk Hydrometeorological Observatory. Leningrad, Gidrometeoizdat, 156 p. (in Russian)]

Борисевич Д.В. (1968) Рельеф и геологическое строение. Урал и Приуралье. Комар И.В., Чикишев А.Г. (ред.) М., Наука, с. 19-81 [Borisevich D.V. (1968) Relief and geological structure. Ural and Priurals. Komar I.V., Chikishev A.G. (Eds.) Moscow, Nauka, p. 19-81 (in Russian)]

Геология СССР (1969) T. ХІІ. Пермская, Свердловская, Челябинская и Курганская области. Часть 1. Геологическое описание. Книга 1. М., Книга по требованию, 777 с. [Geology of the USSR. (1969) Vol. XII. Perm, Sverdlovsk, Chelyabinsk and Kurgan regions. Part 1. Geological description. Book 1. Moscow, Kniga po trebovaniyu, 777 p. (in Russian)]

Горчаковский П.Л., Шиятов С.Г. (1985) Фитоиндикачия условий среды и природных процессов в высокогорьях. М., Наука, 208 с. [Gorchakovsky P.L., Shiyatov S.G. (1985) Phytoindication 
of environmental conditions and natural processes in high mountains. Moscow, Nauka, 208 p. (in Russian)]

Моисеев П.А., Шиятов С.Г., Григорьев А.А. (2016) Климатогенная динамика древесной растительности на верхнем пределе ее распространения на хребте Большой Таганай за последнее столетие. Екатеринбург, 136 с. [Moiseev P.A., Shiyatov S.G., Grigoriev A.A. Climate dynamics of woody vegetation at the upper tree line on the Bolshoi Taganay ridge over the last century. Ekaterinburg, 136 p. (in Russian)]

Шиятов С.Г. (1986) Дендрохронология верхней гранищы леса на Урале. М., Наука, 136 с. [Shiyatov S.G. (1986) Dendrochronology of the upper tree line in the Urals. Moscow, Nauka, 136 p. (in Russian)]

Danby R.K., Hik D.S. (2007) Variability, contingency and rapid change in recent subarctic alpine tree line dynamics. Journal of Ecology, 95: 352-363

IPCC, 2013: Climate Change 2013: The Physical Science Basis. Contribution of Working Group I to the Fifth Assessment Report of the Intergovernmental Panel on Climate Change. Stocker T.F., Qin D., Plattner G.-K., Tignor M., Allen S.K., Boschung J., Nauels A., Xia Y., Bex V., Midgley P.M. (eds.) Cambridge University Press, Cambridge, United Kingdom and New York, NY, USA, 1535 p.

Kullman L., Öberg L. (2009) Post-Little Ice Age tree line rise and climate warming in the Swedish Scandes: a landscape ecological perspective. Journal of Ecology, 97: 415-429

Mazepa V.S. (2005) Stand density in the last millennium at the upper tree-line ecotone in the Polar Ural Mountains. Canadian Journal of Forest Research, 35(9): 2082-2091

Moiseev P.A., Bartish A.A., Nagimov Z.Ya. (2010) Climate changes and tree stand dynamics at the upper limit of their growth in the North Ural mountains. Russian Journal of Ecology, 41(6): 486-497

Schroeter C. (1926) Das Pflanzenleben der Alpen: Eine Schilderung der Hochgebirgsflora. Zuerich, Verlag von Albert Raustein, 1288 p. [Schroeter C. (1926) Plant life in Alps: a description of high mountain flora. Zuerich, Verlag von Albert Raustein, 1288 p. (in German)] 